\title{
Effect of Oil Revenues on Certain Macroeconomic Variables in Selected Oil-Exporting Countries: A Panel Data Approach
}

Submitted 25/03/21, $1^{\text {st }}$ revision 28/04/21, $2^{\text {nd }}$ revision 09/05/21, accepted 30/05/21

\author{
Davood Danesh Jafari ${ }^{1}$, Hamid Nazemian ${ }^{2}$, Javid Bahrami ${ }^{3}$, \\ Mohammad Hassan Kheiravar ${ }^{4}$
}

\begin{abstract}
:
Purpose: This article examines the effect of oil revenues on four macroeconomic variables, including GDP per capita, inflation rate, real exchange rate ${ }_{2}$ and liquidity in selected oilexporting countries over the period 1980-2015.

Design/Methodology/Approach: For this purpose, models are developed in the form of four scenarios and are estimated using panel data.

Findings: The results show that oil revenues have a significant positive effect on the GDP per capita and volume of money, a significant negative effect on the real exchange rate and no significant impact on the inflation rate.

Practical Implications: These findings provide a better understanding of how oil revenues affect the economy of oil-exporting countries and its channels.

Originality/Value: This would help governments improve the quality of resource revenue management, targeting higher economic performance.
\end{abstract}

Keyword: Oil Revenues, macroeconomic variables, oil-exporting countries, panel data.

JEL Classification: $Q 43$.

Research type: Research paper.

\footnotetext{
${ }^{1}$ Assistant Professor, Department of Business Economics, Faculty of Economics, Allameh Tabataba'i University, Tehran,Iran, daneshjafari@atu.ac.ir;

${ }^{2}$ Professor, Department of Theoretical Economics, Faculty of Economics, Allameh Tabataba'i University, Tehran, Iran., nazeman@atu.ac.ir;

${ }^{3}$ Associate Professor, Department of Business Economics, Faculty of Economics, Allameh Tabataba'i University, Tehran,Iran, javid_bahrami@yahoo.com;

${ }^{4}$ Ph.D. Student, Department of Theoretical Economics, Faculty of Economics, Allameh

Tabataba'i University,Tehran,Iran.m_kheiravar@atu.ac.ir;
} 


\section{Introduction}

In recent years, there has been expanding literature on revenues from natural resources and their impacts on resource-rich countries' economy. The considerable number of studies confirm that the excessive reliance on oil revenues and a resourcebased economy has led to various economic problems and the so-called "resource curse" phenomenon. The basic idea is that resource-rich countries generally have lower economic growth rates than resource-poor countries (Mehrara et al., 2010). This is mainly attributed to the exogenous nature of oil revenues and their price volatility, the way these revenues are managed and utilized, and the profound impacts of these revenue shocks and fluctuations when transmitting into the economy. In most oil-exporting countries, these revenues are usually injected into the economy through government spending instead of being invested in infrastructures and institutions, which could accelerate economic development. Rising oil prices lead to a massive, unexpected increase in these countries' revenues. Since it is not the result of economic sectors' activity, this increase in revenues is not an accurate indicator of economic prosperity and even may cause imbalances. In contrast, a drop in oil prices significantly reduces oil exporters' foreign exchange revenues and limits their income sources which can be devastating if the country is highly dependent on oil revenues (Devlin and Lewin, 2005). Consequently, the precise realization of oil revenues' impacts on the main economic variables, its channels, and adopting strategies for mitigating them has become a significant concern and challenge for oil-exporting countries, especially since the 1973 and 1979 oil crises and the subsequent instabilities. This research examines the effect of oil revenues on four macroeconomic variables, i.e., real exchange rate, liquidity, inflation rate, and GDP per capita.

The article is organized into four sections. Section 1 is the introduction, followed by the theoretical framework and literature review in Section 2. Section 3 presents the methodology and the results, and Section 4 provides a summary, conclusion, and some recommendations.

\section{Literature Review}

\subsection{Theoretical Framework}

The most important studies in this area have been conducted since the 1970s oil shocks. Over time and with more and more oil shocks occurring, arguments about the concepts and the channels these shocks affect the economy have expanded. However, despite more than five decades of research, this topic is still controversial. Recent studies have yet revealed different aspects of the complexities of oil revenues and their impacts on macroeconomic variables, which conventional approaches cannot fully capture (Mork, 1989). Regardless of research conducting times and methods, some conclude that oil shocks directly affect macroeconomic variables, but they have also been the main reason for economic downturns. However, others attribute economic problems following oil shocks to a combination of shock impacts and policies adopted to the changes in oil prices and revenues. Time horizon is critical in analyzing 
the impacts of oil shocks on economic variables as it can influence the extent of the economy's adaptation to new conditions. With that being said, most researchers analyze the effects of oil revenues from the short-term perspective (Esfahani et al., 2013). In other words, this is important to consider that the short and long-run effects of oil shocks may be different.

This section, briefly explains common channels through which oil revenues affect the economy of oil-exporting countries.

\subsubsection{Oil revenues, inefficient economic policies, and key economic factors (includ- ing liquidity, inflation rate, real exchange rate, and GDP)}

Many researchers show that oil revenues can destabilize the economy through unstable/inefficient economic policies followed by fluctuating key economic factors. These revenues are a function of global oil prices, making it an essential exogenous variable. The history of the worldwide oil market shows that, at least in the last five decades (since the early 1970s), oil prices have constantly been fluctuating (Hamilton, 2009). Every country tries to curb the impacts of these fluctuating exogenous parameters on its economy as Macroeconomic stability is the cornerstone of sustainable economic growth (Khalili and Ramezanpour, 2001). Thus, one of the government's primary responsibilities is to bring discipline and stability to the economy (Brunnschweiler, 2007). Oil importing countries are also faced with the same situation. They try to mitigate the negative impacts of fluctuations in global oil prices on their economy through tax mechanisms. However, dependence on oil revenues in the national budget and volatile oil prices leads to a lack of financial discipline, followed by instability in key economic factors (Eltejai and Afzali, 2012), if preventive actions are not taken.

Rising oil prices lead to a massive, unexpected increase in oil exporters' revenues which are usually injected into their economy through the state budget. This means government's current and developmental expenditures increase proportionally to oil revenues, and its size and interventions expand relatively (Shahnazi et al., 2011). However, increasing uncontrolled government size and interventions (budget and offbudget) in the economy disrupt market performance, competition, optimal allocation of resources (Sala-I-Martin and Subramanian, 2003), and cause waste, especially because of inefficient public spending and fiscal expansion. As supported by the experiences of oil-exporting countries, significant government investments, especially in less developed ones, do not follow their schedule and objectives. When oil revenues increase, the volume of the government's investment exceeds the predicted values, while return on investments usually decreases due to mismanagement. This simultaneously limits the private sector's investment and the nation's involvement in the economy (Paykarjoo, 2001), and so, governments are getting increasingly and inefficiently more crucial (Ascher, 1999). Another side of the coin is even worse; such a government's accountability to its people and incentives for institution-building may reduce over time which causes failure in implementing growth-enhancing policies and reforms. This situation leads to poorer governance, corruption, embezzlement, and conflicts (Olayungbo and Adediran, 2017). 
As a significant portion of the government's financial resources comes from oil revenues, its fiscal policies may follow the global oil market (despite the annual budget's specific orientation). A considerable number of cases have been reported in oil-exporting countries that unstable and irregular financial behaviors occur, followed by strong fluctuations in global oil prices (Aizenman and Glick, 2008), which directly transmit into public spending and tax rates (Aguilar and Ramírez, 2014). Since these policies strongly depend on the volume of oil revenues, optimistic estimates of oil revenues for a given year and government spending, based on these estimates, could lead to a budget deficit when oil revenues do not match the predicted values. These policies and deficits can affect aggregate demand and interest rates and may influence monetary policies (Aguilar and Ramírez, 2014). In such a situation, the government is usually obliged to borrow mainly through the banking system as the easiest way, which increases the government's net debt to the central bank and leads to an increase in the volume of money and inflation (Hausmann and Rigobon, 2002). Thus, oil exporters' monetary policies would be affected by oil prices and revenues (Rosser and Sheehan, 1995).

On the other hand, the injection of oil revenues into the economy also increases aggregate demand. This amplifies inflation, affecting other economic and sociopolitical factors. In this situation, governments usually try to offset a portion of the increase in demand through imports. It is often not very useful due to poor infrastructure and the rising prices of imported goods, resulting in higher prices and profitability in the nontradable sector than the tradable's.

In addition, the conversion of eolian petrodollars into domestic currencies to compensate for the budget deficit and increased imports cause increasing money supply which is not the outcome of economic activities. This also leads to the deviation of inflation from the equilibrium, especially in non-tradable sectors. The high inflation rate and fluctuations increase the variability of relative prices and distort the decisions made by economic agents. This distortion reduces the strength of the price signaling system and creates uncertainty, which also negatively impacts investment and undermines efficient resource allocation. Moreover, high, irregular, and unstable inflation rates weaken economic growth and worsen income, wealth, and welfare distribution (Dehghan and Pourrahim, 2013).

In contrast, a drop in oil prices significantly limits its exporters' income sources and reduces their foreign exchange revenues. Due to the inflexibility of current government expenditures, which mainly involves government employees' wages and salaries, falling oil prices force the government to reduce its development expenditures in favor of current expenditures. Therefore, it first manifests itself in a large number of unfinished development projects. Even in these circumstances, the public sector cannot reduce its spending proportionate to revenue cuts, thus facing huge deficits (Mehrara and Mohaghegh, 2011). Therefore, we can infer from what has been discussed so far that the negative impacts of increased government spending during the period of the oil revenue boom are not limited to the short run. They persist even when these revenues decline due to the grave sociopolitical consequences of reducing 
government expenditures. However, the fiscal imbalances following an oil price decrease can be devastating if the country is highly dependent on oil revenues (Devlin and Lewin, 2005). This leads to unemployment, especially in sectors that mainly use unskilled workers, and as a result, instability spreads from the economy to political and social spheres (Cuñado and De Garcia, 2005).

Another important factor through which oil revenues may affect oil-exporting economies is the exchange rate. As supported by considerable experiences, oil price volatility and its export revenues' fluctuations transmit to the real exchange rate (Davis et al., 2001; Mehrara and Mohaghegh, 2011) if preventive actions are not taken. The exchange rate is crucial in linking domestic and foreign prices and is one of the most effective means for encouraging and expanding exports while limiting imports (Neary and Van Wijnbergen, 1986). This is so important that many scholars point out its related policies as the main reason behind the 1930s Great Depression.

Generally, changes in the price of exported goods significantly affect exchange rate behavior, and oil is not an exception for its exporters. An increase in oil export's earnings is expected to increase the domestic currency's value in most cases (Berument et al., 2010). It also depends on society's point of view whether the nature of oil price changes is temporary or permanent. This effect is more extreme in a single product economy that gains a significant part of its foreign exchange earnings by exporting oil. In these countries, the exchange rate is not often adjusted to the annual inflation rate. Thus, the nominal exchange rate usually decreases in several consecutive years, increasing imports and reducing foreign exchange reserves.

This situation can cause Dutch disease, which refers to the unexpected overvalued currency, first experienced in the Netherlands, immediately after the revenues earned from discovering natural gas resources within its jurisdiction in the North Sea in the early 1960s (Mohades and Pesaran, 2013). The Dutch disease often occurs at the time of oil revenue booms. While injecting oil revenues into the economy undermines tradable goods' production, which causes national capital transfer into the non-tradable sector, followed by price increases. The Dutch disease ultimately leads to inflationary recession, a challenging problem to deal with (Neary and Van Wijnbergen, 1986).

However, irregular imports encouraged by the overvalued exchange rate and backed by petrodollars reduce foreign-exchange reserves and cannot continue as oil prices decline. In other words, any drop in oil prices significantly limit oil exporters' income sources and reduces their foreign exchange, which may even force abnormal increases in the nominal exchange rate. In addition, shocks such as budget deficit or surplus money supply, common in most oil-dependent countries, also affect the real exchange rate but usually more strongly than other variables. This also leads to its deviation from the long-term balance (Dehghan, Manshadi, and Pourrahim, 2013) and is accounted as one of the factors whose volatility and deviation from the equilibrium level affect other macroeconomic indicators, including economic growth. 


\subsubsection{Oil revenues and some other challenges faced by its exporters}

In addition to the items explained above, this section provides a brief description of the other five challenges that oil-exporting countries may face, as follow. The greater the dependence on oil, the greater the likelihood of being harmed by these challenges.

Terms of trade loss: Many economists have shown that periods of trade are always disadvantageous for oil-dependent developing countries, as the real value of raw material exports continuously declines while the value of imports increases (Prebisch, 1964).

The imbalance between national production and national consumption: When a significant portion of the country's consumption is supplied through oil exports which are not produced but extracted, there would be an imbalance between its production and consumption. Experiences show that countries that have completed the development process establish such a balance and manage to extend their production beyond their consumption over a significant time. The greater the imbalance, the farther the country will be from development (Hassan Tash and Naderian, 2009).

Rent-seeking: Oil extraction costs are negligible compared to the revenues which it generates. That is why these revenues are regarded as economic rents, and oil exporters are often referred to as rentier states that mainly play the role of rent distributors. Rent-seeking behavior is considered unsavory and unproductive in the economic literatures. This phenomenon and economic instability reduce the risk-taking of economic agents and amplify limitations on business activities, as everyone tries to get their hands on rents (Bardhan, 1997). Rent-seeking also tends to manifest itself through capital stock's equilibrium level and, finally, would negatively influence sustainable economic growth (Esfahani et al., 2014).

Weakening of human and social capital: Human and social capital is the country's most critical resources and are considered as one of the important factors that are adjudged to influence economic performance (Hadjimicheal et al., 1994). However, an abundance of natural resources and related revenues' inherent independence from the country's economic activities reduces the importance of human capital in country's production and income creation process (Godwin and Chuka, 2014). At the same time, this undermines the relationship between a nation and its state and government's representation role. In such a situation, country's social capital is usually reducing, which also tends to inhibit economic growth (Gylfason et al., 1999).

Foreign interventions: Another issue that should not be overlooked is foreign intervention. In comparison, almost all poor, undeveloped countries are subject to postcolonial interventions. However, the risk is greater for oil exporters as world powers compete to control oil limited and depletable reserves and its extraction to meet their own needs, ensure the flow of oil exports, and gain an advantage over their competitors (Hassan Tash and Naderian, 2009). The geographical distance between central oil reserves has also turned oil into a critical geopolitical issue. 


\subsection{Empirical Studies}

Some empirical studies employed the VAR model (Ahmad and Masan, 2015; Farzangan and Markwardt, 2009; Komijani and Nazari, 2015; Mohammadi and Barat, 2013; Shahbazi et al., 2012), OLS model (Radnia, 2013; Roshani, 2016), panel data model (Etemad, 2014; Zonouzi et al., 2014), Johansen model (Masan, 2016), AR(1) model (Bova et al., 2018), SVAR model (Mehrara and Oskoui, 2006), SUR method (Arman and Aghajari, 2009), VECM model (Komijani et al., 2012), and DSGEBVAR (Esmailipour et al., 2017) to investigate the effect of oil revenues on various macroeconomic variables.

Ahmad and Masan (2015) examined the dynamic relationships between oil revenues, government spending, and Oman's economic growth in 1971-2013. They found that there is a long-run relationship between GDP, government expenditures, and oil revenues. Government expenditures seem to be the primary source of long-run economic growth, while in the short run, changes in government expenditures are mainly driven by oil revenue shocks. Komijani and Nazari (2015) investigated oil revenues' effect on Iran's government expenditures in 1974-2011. They found that oil revenues have a significant positive impact on government expenditures (total, consumption, and development), both in the short and long run.

Mohammadi and Barat (2013) studied shocks' effect from a reduction in oil revenues on government spending and money supply in Iran in 1980-2010. They concluded that oil revenue shocks significantly affect the government's development and current expenditures and the money supply. Shahbazi et al. (2012) compared the impact of oil shocks on macroeconomic variables, GDP, government expenditures, and inflation in Iran in 1980-2010. They indicated that macroeconomic variables are not significantly affected by these shocks, which can be attributed to policy decisions made in response to these shocks.

By applying a VAR approach, Farzanegan and Markwardt (2009) studied the effects of oil price shocks on the four key macroeconomic factors i.e., inflation, industrial output growth, real government expenditures, and real exchange rate with focus on the post Iran-Iraq war period (spanned from 1975 to 1988). They conclude that positive oil price shocks increase the real exchange rate and cause an appreciation of domestic currency in the mid-run, which is the most important symptom of Dutch disease. In addition, they pointed out that positive as well as negative oil price shocks significantly increase inflation. Their finding also shows strong positive relationships between oil prices and industrial output growth. However, they conclude that real government expenditures only increase in the mid-run and are marginally significant compared to oil price shocks.

Radnia (2013) employed the OLS model and examined the relationship between inflation rate, oil revenues, and taxation in Iran during 1971-2008. She concluded that oil revenues and corporate tax are significant variables for measuring a consumer 
price index. Using a similar model, Roshani (2016) investigated the effect of oil revenues on money volume in Iran and the role of foreign exchange funds in 1963-2013. The results indicated that oil revenues have a considerable impact on the country's money volume. Each petrodollar spent in the country increases the money supply by 6.5 times its value in rials due to the strengthening of foreign-exchange reserves, increased imports, etc. The effect of oil revenues on other components of money volume also confirms this finding.

Using a panel data model, Etemad (2014) explored the effectiveness of sovereign oil funds as fiscal stability instruments in oil-exporting countries during 1980-2009. He concluded that sovereign oil funds stabilize oil-exporting economies by avoiding fluctuations in government spending, inflation, exchange rate, and the monetary base. Zonouzi et al. (2014) also used a similar model by examining the effect of oil revenues on good governance in selected OPEC member countries in 1996-2011. They found that oil revenues have a significant negative effect on good governance, suggesting the negative impact of oil revenues on corruption control, political stability, and accountability. Oil revenues also harm government effectiveness and the quality of laws and positively impact the rule of law, but these effects are not significant.

Applying the Johansen model, Masan (2016) explored the relationship between oil revenue and macroeconomic policies in of 1980-2004 and indicated that three main components of the government expenditure (i.e., health, education, and military) have positively and significantly responded to a positive oil revenue shock, while military expenditure has recorded the highest response. Bova et al. (2018) used AR(1) model and examined resource revenue volatility and macro-economic stability in resourcerich countries and fiscal policy's role in 1980-2004. They concluded that Non-commodity revenues (resource revenues) tend to respond only to persistent commodity price changes.

By employing the SVAR model, Mehrara and Oskoui (2006) studied the dynamic effects of oil shocks on economic variables in 1960-2003. They found that oil price shocks positively impact imports, GDP, and the price index. Arman and Aghajari (2009) used the SUR method and considered the effect of oil revenues on inflation and growth rate before the 1993 currency modification in Iran during 1960-1990. They found that oil revenues have a direct but slow effect on the growth rate. The inflation rate is indirectly affected by oil revenues through foreign prices and actual exchange rates. The net result is that higher oil revenues tend to reduce inflation, which has reached its highest levels after the 1979 Revolution. The volatility of the inflation rate and the economic growth rate has been largely due to fluctuations in oil revenues and not necessarily due to increases in these revenues.

Komijani et al. (2012) employed the VECM model and studied the asymmetrical effects of oil revenue growth on Iran's inflation in 1971-2008 and indicated that both positive and negative shocks from oil revenue growth are inflationary. Esmailipour et al. (2017) used DSGE-BVAR and examined external shocks' effect on Iran's oildependent economy. The results of their study revealed that monetary shocks and oil 
revenues increase production in the short run, but production decreases as the general price level increases. Foreign exchange shocks reduce production in the short run but increase investments in the long run. Inflation rate increases due to growth in monetary base, oil revenues, and exchange rate shocks but decreases with positive technology shocks.

\section{Methodology and Results}

The effect of oil revenues on four macroeconomic variables is examined, i.e., GDP per capita, inflation rate, money volume, and real exchange rate. Models are developed in the form of four scenarios:

1. Scenario A: The effect of oil revenues on economic growth

$l y_{i t}=\beta_{0}+\beta_{1}(\text { oilrevenue })_{i t}+\beta_{2}(\text { linf })_{i t}+\beta_{3}(\text { lopen })_{i t}+\beta_{3}(\text { lexc })_{i t}+\varepsilon_{i t}$

2. Scenario B: The effect of oil revenues on inflation rate

$\operatorname{linf}_{i t}=\beta_{0}+\beta_{1}(\text { oilrevenue })_{i t}+\beta_{2}(\text { ly })_{i t}+\beta_{3}(\text { lopen })_{i t}+\beta_{3}(\operatorname{lm} 2)_{i t}+\varepsilon_{i t}$

3. Scenario C: The effect of oil revenues on exchange rate

lexc $_{i t}=\beta_{0}+\beta_{1}(\text { oilrevenue })_{i t}+\beta_{2}(\text { ly })_{i t}+\beta_{3}(\text { lopen })_{i t}+\beta_{3}(\operatorname{lm} 2)_{i t}+\varepsilon_{i t}$

4. Scenario D: The effect of oil revenues on money volume

$\operatorname{lm} 2_{i t}=\beta_{0}+\beta_{1}(\text { oilrevenue })_{i t}+\beta_{2}(\text { ly })_{i t}+\beta_{3}(\text { lopen })_{i t}+\beta_{3}(\text { lexc })_{i t}+\varepsilon_{i t}$

Where $y$ is the GDP, exc is the real exchange rate, oilrev is oil revenues, inf is the inflation rate, open is the degree of economic openness, $m 2$ is the volume of money, and $i$ and $t$ respectively denote country and period.

\subsection{Estimation Results for Selected Oil Exporting Countries ${ }^{5}$}

\subsubsection{Stationarity Test}

The first step in time series estimation is testing for stationarity of the variables, as non-stationary series in econometrics estimations lead to spurious regression wich results will not be reliable or interpretable. Unlike time series data, panel data cannot be tested for stationarity using the Dickey-Fuller test or augmented Dickey-Fuller test. For panel data, the Levin-Lin-Chu Test (LLC), the Im-Pesaran-Shin test (IPS), Fisher-ADF, the Phillips-Perron test, the Choi test, the Breitung test, and the Hardi

${ }_{5}^{5}$ Algeira, Angola, Canada, Ecuador, England, Indonesia, Iraq, Iran, Kuwait, Libya, Nigeria, Norway, Qatar, Russia, Saudi Arabia, United Arab emirates and Venezuela. 
test have been proposed. In this research, LLC is used to test for stationarity of the variables with the following hypotheses:

- $H_{0}:$ Variable contains a unit root.

- $\boldsymbol{H}_{1}$ : Variable is stationary.

If the test statistic's absolute value is less than the absolute value of critical values and/or the test probability is less than 0.05 , the null hypothesis is rejected, and the variable is stationary. The results of this test are demonstrated in Table 1.

The LLC test results indicate that LGDPPC, LEXC, LMONEY, and LOPEN contain a unit root $(\mathrm{p}<0.05)$ and are stationary by differencing. LOIREV and LINF are stationary at level.

Table 1. The Results of Unit Root Test Using LLC

\begin{tabular}{|c|c|c|c|c|c|c|c|c|}
\hline Variable & Proxy & $\begin{array}{l}\text { Test } \\
\text { Condi- } \\
\text { tions }\end{array}$ & $\begin{array}{l}\text { Test } \\
\text { Sta- } \\
\text { tistic }\end{array}$ & $\begin{array}{l}p \text { - } \\
\text { value }\end{array}$ & $\begin{array}{l}\text { Test } \\
\text { Condi- } \\
\text { tions }\end{array}$ & $\begin{array}{l}\text { Test } \\
\text { Sta- } \\
\text { tistic }\end{array}$ & $\begin{array}{l}p \text { - } \\
\text { value }\end{array}$ & $\begin{array}{l}\text { Re- } \\
\text { sult }\end{array}$ \\
\hline $\begin{array}{l}\text { Log of GDP } \\
\text { per capita }\end{array}$ & LGDPPC & $\begin{array}{l}\text { With in- } \\
\text { tercept }\end{array}$ & -0.76 & 0.22 & $\begin{array}{l}\text { With in- } \\
\text { tercept } \\
\text { and trend }\end{array}$ & -9.71 & 0.000 & $\mathrm{I}(1)$ \\
\hline $\begin{array}{l}\text { Log of oil } \\
\text { revenues }\end{array}$ & LOILREV & $\begin{array}{l}\text { With in- } \\
\text { tercept }\end{array}$ & 0.64 & 0.74 & $\begin{array}{l}\text { With in- } \\
\text { tercept } \\
\text { and trend }\end{array}$ & -1.82 & 0.03 & $\mathrm{I}(0)$ \\
\hline $\begin{array}{l}\text { Log of real } \\
\text { exchange } \\
\text { rate }\end{array}$ & LEXC & $\begin{array}{l}\text { With in- } \\
\text { tercept }\end{array}$ & -19.44 & 0.000 & $\begin{array}{l}\text { With in- } \\
\text { tercept } \\
\text { and trend }\end{array}$ & -16.8 & 0.000 & $\mathrm{I}(1)$ \\
\hline $\begin{array}{l}\text { Log of infla- } \\
\text { tion rate }\end{array}$ & LINF & $\begin{array}{l}\text { With in- } \\
\text { tercept }\end{array}$ & -4.036 & 0.000 & $\begin{array}{l}\text { With in- } \\
\text { tercept } \\
\text { and trend }\end{array}$ & -3.94 & 0.000 & $\mathrm{I}(0)$ \\
\hline $\begin{array}{l}\text { Log of eco- } \\
\text { nomic open- } \\
\text { ness }\end{array}$ & LOPEN & $\begin{array}{l}\text { With in- } \\
\text { tercept }\end{array}$ & -18.04 & 0.000 & $\begin{array}{l}\text { With in- } \\
\text { tercept } \\
\text { and trend }\end{array}$ & -16.68 & 0.000 & $\mathrm{I}(1)$ \\
\hline $\begin{array}{l}\text { Log of } \\
\text { money vol- } \\
\text { ume }\end{array}$ & LMONEY & $\begin{array}{l}\text { With in- } \\
\text { tercept }\end{array}$ & -11.40 & 0.000 & $\begin{array}{l}\text { With in- } \\
\text { tercept } \\
\text { and trend }\end{array}$ & -11.95 & 0.000 & $\mathrm{I}(1)$ \\
\hline
\end{tabular}

Source: Present research calculations.

The cointegration test is also used as a pretest to avoid non-stationarity and spurious regression. Pedroni (2004) and Kao (1999) panel cointegration tests are used in this research. The results are presented in Tables 2 and 3.

\subsubsection{Cointegration Test}

The most critical point in cointegration analysis is that, although most time series are non-stationary and have a random upward or downward trend in the long run, a linear combination of theses variables may always be stationary and without trend. These long-run relationships are discovered using cointegration analysis. In other words, if a hypothesis is true and a set of variables are correlated, we expect the combination of these variables to be stationary and without a trend in the long run. Similar to time 
series, it is crucial to examine the cointegration of the variables in panel data. Panel cointegration tests are more powerful and reliable than cointegration tests for separate cross-sections. These tests are applicable even in a short-run horizon and small sample size.

Cointegration can be considered an estimation technique for long-run equilibrium coefficients of a model whose variables have unit root and are thus non-stationary. Although the stationarity condition for time series variables can be met through differencing, this leads to the loss of valuable information about the variables' level. Cointegration allows for estimating a regression based on time series variables without any concern for a spurious correlation. Various cointegration tests have been proposed with entirely different approaches, including Pedroni (2004) and Kao (1999) panel cointegration tests. These two approaches are based on testing regression residuals and are similar to Engle and Granger's (1987) cointegration test for time series data.

It must be noted that the cointegration test only shows the presence or absence of a long-run relationship and does not determine the strength or direction of the relationship. The results of the Kao test for all the models are presented in Table 2.

Table 2. The Results of Kao Panel Cointegration Test with Intercept

\begin{tabular}{l|ll}
\hline \multicolumn{2}{c}{ t-statistic } & \multicolumn{2}{c}{ Prob. } \\
\hline MODEL 1 & 0.6 & 0.27 \\
ADF & 0.01 & \\
Residual variance & 0.02 & \\
HAC variance & & 0.00 \\
MODEL 2 & -2.99 & \\
ADF & 0.51 & \\
Residual variance & 0.44 & \\
HAC variance & & \\
MODEL 3 & -3.06 & \\
ADF & 0.02 & \\
Residual variance & 0.03 & \\
HAC variance & & \\
MODEL 4 & -1.64 & \\
ADF & 0.02 & \\
Residual variance & 0.03 & \\
HAC variance &
\end{tabular}

Source: Own creation.

The KAO test results indicate that the ADF statistic is significant at the 0.05 level for models 2, 3, and 4. Therefore, the null hypothesis for the absence of cointegration in the variables is rejected. Thus, the long-run relationships exist between oil revenues, GDP per capita, inflation rate, economic openness, money volume, and real exchange rate, and they are co-integrated. However, long-run relationships in model 1 are not observed. 


\subsection{Diagnostic Tests}

The models of the present research are estimated using panel data. An essential issue in applied studies is whether data can be pooled or that the model yields different results at different times. In the case of heterogeneities and individual differences, pooled data analysis must be used. Therefore, we must first test the significance of individual effects before any estimation.

\subsubsection{F-limer Test}

The F-limer test is used to test for the significance of individual effects. At a given significance level, if the calculated $\mathrm{F}$ is greater than the table value of $\mathrm{F}$ with $(\mathrm{N}-1)$ degree of freedom and (NT-N-K) denominator, the null hypothesis for non-significance of individual effects is rejected and the model is estimated as panel data. The results of the F-Limer test are presented in Table 3.

Table 3. The Results of the F-Limer Test

\begin{tabular}{l|lll}
\hline Model & Test & Statistic & Prob. \\
\hline Model 1 & Cross-Section F & 267.73 & 0.00 \\
Model 2 & Cross-Section F & 15.46 & 0.00 \\
Model 3 & Cross-Section F & 18.42 & 0.00 \\
Model 4 & Cross-Section F & 198.37 & 0.00 \\
\hline
\end{tabular}

Source: Present research calculations.

As the data in Table 3 show, the probability of the F statistic is less than 0.01 . Therefore, at the $99 \%$ confidence interval (CI), the calculated F statistics indicated that the null hypothesis for group estimation is rejected, and the models' estimation as panel data are confirmed.

\subsubsection{Hausman Test}

Given the results of the F-Limer test, panel data must be used to estimate the specified models. At this stage, the Hausman test is used to find whether fixed or random effects can better explain the differences in the intercepts of cross-section units. The null hypothesis for consistency of random effects estimators is tested against the alternative hypothesis for the inconsistency of random effects estimators (i.e., consistency of fixed effects estimators). The results of the Hausman test are provided in Table 4.

Table 4. The Results of Hausman Test

\begin{tabular}{l|lll}
\hline Model & Test & Statistic & Prob. \\
\hline Model 1 & Hausman test & 18.76 & 0.00 \\
Model 2 & Hausman test & 16.81 & 0.00 \\
Model 3 & Hausman test & 68.49 & 0.00 \\
Model 4 & Hausman test & 12.34 & 0.01 \\
\hline
\end{tabular}

Source: Present research calculations.

The Hausman test results show that the probability for models 1, 2, 3, and 4 is 0.0000 , 
$0.0021,0.0000$, and 0.015 , respectively, below the 0.05 significance level. Therefore, the null hypothesis for consistency of random effects estimators is rejected, and the models are estimated using panel data with fixed effects.

Given the results of the F-Limer test and Hausman tests, Tables 5, 6, 7, and 8 show the results of estimating the specified models for the effect of oil revenues on macroeconomic variables in selected oil-exporting countries over the period 1980-2015 using panel data and the generalized least squares (GLS) technique.

\subsection{Model Estimation}

The results of estimating the first model show that the log of oil revenues with a coefficient of 0.44 has a significant positive effect on the log of GDP per capita at the 0.01 level. In other words, a one percent increase in the log of oil revenues increases GDP per capita by 0.44 percent. Therefore, rising oil revenues lead to an improvement in GDP per capita in the same period. The log of inflation rate with a coefficient of 0.02 has a positive effect on the log of GDP per capita, but this effect is not statistically significant at the 0.01 level. The log of a real exchange rate with a coefficient of 0.14 has a significant positive effect on GDP per capita at the 0.01 level. One percent increase in real exchange rate leads to a 0.14 percent increase in these countries' GDP per capita. Finally, the log of economic openness with a coefficient of 0.14 has a significant positive effect on GDP per capita at the 0.01 level. A one percent increase in the degree of economic openness leads to a 0.14 percent increase in the GDP per capita of these countries.

Table 5. The Results of Estimating the First Model in Selected Oil-Exporting Countries (Dependent Variable: Log of GDP per Capita)

\begin{tabular}{l|llll}
\hline Variable & Proxy & Coefficient & $\boldsymbol{t}$-statistic & Prob. \\
\hline Intercept & C & 3.65 & 25.27 & 0.00 \\
Log of oil revenues & LOILREV & 0.44 & 50.78 & 0.00 \\
$\begin{array}{l}\text { Log of inflation } \\
\text { Log of real ex- } \\
\text { change rate }\end{array}$ & LINF & 0.02 & 1.39 & 0.16 \\
$\begin{array}{l}\text { Log of economic } \\
\text { openness }\end{array}$ & LOPEN & 0.14 & 5.91 & 0.00 \\
\hline $\boldsymbol{R}^{\mathbf{2}=0.96 ; \text { adjusted }} \boldsymbol{R}^{\mathbf{2}}=0.96 ;$ F statistics = 558.92; F prob. =0.0000; Durbin-Watson statistic = \\
0.38
\end{tabular}

Source: Present research calculations.

The results of estimating the second model show that the log of oil revenues with a coefficient of 0.05 has a positive effect on the log of the inflation rate, but the effect is not statistically significant. Therefore, oil revenues have no significant impact on the inflation rate in the selected oil exporting countries. The log of GDP per capita with a coefficient of -0.15 harms the inflation rate, but the effect is not statistically significant. The log of money volume with a coefficient of 0.06 has a significant positive effect on the inflation rate log at the 0.05 level. This means one percent increase in money volume increases the inflation rate by 0.06 percent in these countries. The 
$\log$ of economic openness with a coefficient of 0.38 has a significant positive effect on the inflation rate log at the 0.01 level. One percent increase in economic openness increases the inflation rate by 0.38 percent in these countries.

Table 6. The Results of Estimating the Second Model in Selected Oil-Exporting Countries (Dependent Variable: Log of Inflation Rate)

\begin{tabular}{l|llll}
\hline Variable & Proxy & Coefficient & $\boldsymbol{t}$-statistic & Prob. \\
\hline Intercept & C & 3.18 & 3.47 & 0.00 \\
Log of oil revenues & LOILREV & 0.05 & 0.77 & 0.44 \\
Log of inflation & LGDPPC & -0.15 & -1.04 & 0.29 \\
$\begin{array}{l}\text { Log of economic } \\
\text { openness }\end{array}$ & LOPEN & 0.38 & 3.41 & 0.00 \\
$\begin{array}{l}\text { Log of money vol- } \\
\text { ume }\end{array}$ & LM2 & 0.06 & 2.14 & 0.03 \\
\hline $\boldsymbol{R}^{2}=0.58 ;$ adjusted $\boldsymbol{R}^{2}=0.56 ;$ F statistics $=25.27 ;$ F prob. $=0.0000 ;$ Durbin-Watson statistic $=0.89$
\end{tabular}

Source: Present research calculations.

The results of estimating the third model indicate that the log of oil revenues with a coefficient of -0.12 has a significant negative effect on the actual exchange rate log in the selected oil-exporting countries. This means a one percent increase in the log of oil revenues decreases the actual exchange rate log by 0.12 percent. The log of GDP per capita with a coefficient of 0.3 has a significant positive effect on the actual exchange rate log. In other words, a one percent increase in the log of GDP per capita increases the actual exchange rate log by 0.3 percent in these countries. The log of money volume with a coefficient of -0.11 has a significant negative effect on the actual exchange rate log at the 0.01 level. One percent increase in money volume decreases the real exchange rate by 0.11 percent in these countries. Finally, the log of economic openness with a coefficient of -0.11 has a significant adverse effect on the actual exchange rate $\log$ at the 0.05 level. A one percent increase in the degree of economic openness decreases the real exchange rate by 0.11 percent in these countries.

Table 7. The Results of Estimating the Third Model on Selected Oil-Exporting Countries (Dependent Variable: Log of Real Exchange Rate)

\begin{tabular}{l|llll}
\hline Variable & Proxy & Coefficient & $\boldsymbol{t}$-statistic & Prob. \\
\hline Intercept & C & 4.1 & 11.44 & 0.00 \\
$\begin{array}{l}\text { Log of oil revenues } \\
\text { Log of money vol- }\end{array}$ & LOILREV & -0.12 & -2.87 & 0.00 \\
$\begin{array}{l}\text { ume } \\
\text { Log of GDP per } \\
\text { capita }\end{array}$ & LGDPPC & -0.11 & -4.71 & 0.00 \\
$\begin{array}{l}\text { Log of economic } \\
\text { openness }\end{array}$ & LOPEN & -0.3 & 4.31 & 0.00 \\
$\boldsymbol{R}^{2}=0.53 ;$ adjusted $\boldsymbol{R}^{2}=0.51 ;$ F statistics $=22.51 ;$ F prob. $=0.0000 ;$ Durbin-Watson statistic $=0.37$
\end{tabular}

Source: Present research calculations.

The results of estimating the fourth model show that the log of oil revenues with a coefficient of 0.53 has a significant positive effect on the log of money volume at the 0.01 level. It means, one percent increase in the log of oil revenues increases the $\log$ 
of money volume by 0.53 percent in the selected oil-exporting countries. The log of GDP per capita with a coefficient of 0.15 has a positive effect on money volume in these countries, but the effect is not statistically significant. The log of a real exchange rate with a coefficient of -1 has a significant negative effect on the log of money volume at the 0.01 level. In other words, a one percent increase in real exchange rate decreases money volume by one percent in these countries. The log of economic openness with a coefficient of 0.32 has a significant positive effect on the money volume log at the 0.05 level. One percent increase in the degree of economic openness increases money volume by 0.32 percent in these countries.

Table 8. The Results of Estimating the Fourth Model in Selected Oil-Exporting Countries (Dependent Variable: Log of Money Volume)

\begin{tabular}{|c|c|c|c|c|}
\hline Variable & Proxy & Coefficient & $t$-statistic & Prob. \\
\hline Intercept & $\mathrm{C}$ & 4.46 & 2.95 & 0.00 \\
\hline Log of oil revenues & LOILREV & 0.53 & 4.15 & 0.00 \\
\hline $\begin{array}{l}\text { Log of GDP per } \\
\text { capita }\end{array}$ & LGDPPC & 0.15 & 0.82 & 0.00 \\
\hline $\begin{array}{l}\text { Log of real ex- } \\
\text { change rate }\end{array}$ & LEXC & -1 & -4.28 & 0.00 \\
\hline $\begin{array}{l}\text { Log of economic } \\
\text { openness }\end{array}$ & LOPEN & 0.32 & 2.02 & 0.00 \\
\hline
\end{tabular}

Source: Present research calculations.

\section{Conclusions}

One of the key issues for oil exporting countries is to manage underground reserves and related revenues in a way that contributes to the economic growth and development of countries, which in turn increases living standards and welfare while reducing poverty. Obviously, to achieve this, understanding the way and direction of oil revenues' impacts on key economic factors is an essential issue. However, despite of plenty of research in this context, the effect of oil revenues on the economy of oil exporters is yet a controversial discussion. In addition to oil price historical volatility and exogenous nature of oil revenues, these impacts are primarily dependent upon these countries' economic structure, their governments' policies, and spending behavior.

In most oil-dependent countries, oil revenues are injected into the economy through the government budget. These revenues account for a large portion of foreign-exchange reserves, governments' income, and their expenditures in such economies. Given the government's dominant role in these economies and oil revenues characteristics, these revenues affect various macroeconomic factors such as the budget deficit, economic growth, consumption, national savings, investment, exchange rate, and inflation rate, leading to socioeconomic and even political instability.

The present article examined the effect of oil revenues on four critical macroeco- 
nomic variables (i.e., GDP per capita, money volume, inflation rate, and real exchange rate) in selected oil-exporting countries over the period 1980-2015. For this purpose, models are developed in four scenarios and are estimated using panel data.

First, the LLC unit root test was used to test for stationarity. The results showed that the log of GDP per capita, the log of the real exchange rate, the log of money volume, and the log of economic openness contained a unit root and were stationarized by differencing. However, the log of the inflation rate and the log of oil revenues were stationary at a level. Next, the variables' cointegration was examined using the Kao test. The results indicated cointegration between oil revenues, GDP per capita, inflation rate, economic openness, money volume, and real exchange rate in models 2,3 , and 4. In contrast, long-run relationships were not confirmed for model 1.

Afterward, the models were estimated. The results of evaluating the first model showed that oil revenues had a significant positive effect on GDP per capita (0.44), but no long-run relationship has been demonstrated between these variables. Therefore, we can argue that oil revenues increase GDP per capita in the short run. This can be attributed to the fact that oil revenues are not the result of economic sectors' activity and do not reflect actual economic prosperity

Estimation of the second model showed that oil revenues have no significant effect on the inflation rate. It can be analyzed that any increase or decrease in oil revenues may cause an increase in the inflation rate through different channels. In short, an increase in oil revenues can amplify inflation as petrodollars are converted into domestic currency and injected into the economy while supply elasticity is low. On the other hand, a decrease in oil revenues also increases the inflation rate by reducing imports, budget deficit, and, in some cases, increasing the volume of money.

The results of estimating the third model for the selected oil-exporting countries showed the significant negative effect of oil revenues on the real exchange rate $(-0.12)$. Finally, in the fourth model, oil revenues significantly affected money volume (0.53). Foreign exchange revenues from oil sales, increase the central bank's foreign assets as a component of the monetary base. This can lead to an increase in the volume of money, expand imports, and lower the real exchange rate, which reduces the competitiveness of oil-exporting countries. Based on model estimations, oil revenues have the highest effect on money volume.

In most oil-exporting countries, governments consider rising oil prices as constant and falling oil prices as temporary. Therefore, they tend to develop unrealistic and unachievable policies. Price fluctuations due to oil shocks can be managed appropriately, and their negative effects can be prevented through conservative price predictions, adjustment of government expenditures based on constant (rather than temporary) changes in oil revenues, and effective use of an oil revenue savings account or fund. Limiting the government's access to surplus oil revenues and reducing its share of these revenues will constrain inflationary effects and other related undesirable effects. Also, adopting appropriate foreign trade policies can mitigate the vulnerability 
of these countries to oil revenue fluctuations. Besides, through proper management of the exchange rate, especially during oil booms, policymakers can prevent an overvalued national currency that disrupts international commerce and makes the tradable sector vulnerable to shocks.

\section{References:}

Aguilar, A.M., Ramírez, C. 2014. Oil dependent revenues and macroeconomic stability under fiscal and monetary rules: An analysis for Mexico. Fiscal Policy and Macroeconomic Imbalances, 16, 751-783.

Ahmad, A., Masan, S. 2015. Dynamic relationships between oil revenue, government spending and economic growth in Oman. International Journal of Business and Economic Development, 3(2), 93-115.

Aizenman, J., Reuven, G. 2008. Sovereign wealth funds: Stylized facts about their determ nants and governance. International Finance, 12(3), 351-386.

Bardhan, P. 1997. Corruption and development: A review of the issues. Journal of Economic Literature, 35(3), 1320-1346.

Berument, H., Ceylan, N.B., Dogan, N. 2010. The impact of oil price shocks on the economic growth of the selected MENA countries. The Energy Journal, 31(1), 149176.

Bova, E., Medas, P., Poghosyan, T. 2018. Macroeconomic stability in resource-rich countries: The role of fiscal policy. Journal of Banking and Financial Economics, 1(9), 103-122.

Brunnschweiler, C.N. 2007. Cursing the blessing? Natural resource abundance, institutions, and economic growth. World Development, 36(3), 399-419.

Cuñado, J., Garcia de, F.P. 2005. Oil prices, economic activity and inflation: Evidence for some Asian countries. The Quarterly Review of Economics and Finance, 45(1), 65-83.

Davis, J.R., Ossowski, J.D., Barnett, S. 2001. Oil funds: Problems posing as solutions? Finance and Development, 38(4), 56-59.

Dehghan, M.M., Pourrahim, P. 2013. The relationship between macroeconomic instability and economic growth in Iran. Iranian Journal of Economics Research and Policy, 21(67), 171-192.

Devlin, J., Lewin, M. 2005. Managing oil booms and busts in developing countries. Managing Economic Volatility and Crises: A Practitioner's Guide. Cambridge University Press, 186-209.

Engle, R.F., Granger, C.W. 1987. Co-integration and error correction: representation, estimation, and testing. Econometrica: Journal of the Econometric Society, 55(2), 251-276.

Eltejai, E., Arbab Afzali, M. 2012. Asymmetrical effect of oil revenues on macroeconomic variables in Iran: A SVAR-GARCH approach. Iranian Journal of Economic Development Research, 2(7), 89-110.

Esfahani, H.S., Mohaddes, K., Pesaran, M.H. 2014. An empirical growth model for major oil exporters. Journal of Applied Econometrics, 29(1), 1-21.

Esfahani, H.S., Mohaddes, K., Pesaran, M.H. 2013. Oil exports and the Iranian economy. The Quarterly Review of Economics and Finance, 53(3), 221-237.

Esmailipour, E., Shirinbakhsh, S., Ebrahimi, I. 2017. The effect of external shocks on Iran's oilbased economy: A DSGE-BVAR approach. Iranian Journal of Applied Economic Theories, 4(2), 49-78.

Etemad, A. 2014. Effectiveness of sovereign oil funds as instruments of fiscal stability: A 
time-series and panel data analysis of the relationship between real government spending and real oil export earnings. Available at SSRN 2435849.

Farzanegan, M.R., Markwardt, G. 2009. The effects of oil price shock on the Iranian economy. Energy Economics, 31(1), 134-151.

Godwin, E.A., Chuka, C. 2014. Natural resources, human capital, and economic development in Nigeria: Tracing the linkages. Journal of Economics and Sustainable Development, 5(20), 35-52.

Gylfason, T., Herbertsson, T., Zoega, G. 1999. Mixed blessing: Natural resources and economic growth. Macroeconomic Dynamics, 3(2), 204-225.

Hadjimicheal, M.T., Dhaneshwar, G., Martint, M., Roger, N., Ucer, E.M. 1994. Effects of macroeconomic stability on growth, saving and investment in Sub-Saharan Africa: An empirical invtigation. IMF Working Paper, 98.

Hamilton, J.D. 2009. Causes and consequences of the oil shock of 2007-08. Working Paper Series, National Bureau of Economic Research.

Hassan Tash, G., Naderian, M.E. 2009. Evaluation of the potential and advantages of energy intensity reduction in OPEC member countries. Iranian Journal of Energy Economics, 16(28), 29-40.

Hausmann, R., Rigobon, R. 2002. An alternative interpretation of the 'Resource Curse': Theory and policy Implications. Working Paper Series, National Bureau of Economic Research, WP 9424.

Kao, C. 1999. Spurious regression and residual-based tests for cointegration in panel data. Journal of Econometrics, 90(1), 1-44.

Khalili Araqi, M., Ramezanpour, E. 2001. Importance of Stability in the Macroeconomic Environment. Economic Research Journal, 58.

Komijani, A., Sobhanian, M.H., Bayat, S. 2012. Asymmetric effects of growth in oil revenues on inflation in Iran: A VECM approach. Iranian Journal of Economics Research, 12(45), 201-216.

Komijani, A., Nazari, R. 2015. Effect of oil revenues on government expenditures in Iran. Empirical Economics Studies Bimonthly, 2.

Masan, S. 2016. Oil and macroeconomic policies and performance in Oman. Doctoral Thesis, Loughborough University.

Mehrara, M., Abrishami, H., Zamanzadeh, H. 2010. A new interpretation of resource curse in oil-exporting countries. Iranian Journal of Energy Economics, 8(28), 134-119.

Mehrara, M., Mohaghegh, M. 2011. Macroeconomic dynamics in the oil exporting countries: A panel VAR study. International Journal of Business and Social Science, 2(21), 288-295.

Mehrara, M., Oskoui, N.K. 2006. Dynamic effects of oil price shocks on macroeconomic variables. Iranian Journal of Commerce, 10(40), 1-32.

Mohaddes, K., Pesaran, M.H. 2013. One hundred years of oil income and the Iranian economy: A curse or a blessing? Iran and the Global Economy, 28-61.

Mohammadi, H., Barat, A. 2013. Effect of shocks from drop in oil revenues on government expenditures and money supply in Iran. Iranian Energy Economics Journal, 2(7), $129-145$.

Mork, K.A. 1989. Oil and the macroeconomy when prices go up and down: An extension of Hamilton's results. Journal of Political Economy, 97(3), 740-744.

Neary, J.P., van Wijnbergen, S. 1986. Natural resources and the macroeconomy: A theoretical framework. Basil Blackwell Ltd, Oxford.

Olayungbo, D.O., Adediran, A. 2017. Effects of oil revenue and institutional quality on economic growth with an ARDL approach. Energy and Policy Research, 4(1), 44-54.

Paykarjoo, K. 2001. An introduction to oil economy concepts. Tehran, Negahe Danesh. 
Pedroni, P. 2004. Panel cointegration: asymptotic and finite sample properties of pooled time series tests with an application to the PPP hypothesis. Econometric Theory, 20(3), 597-625.

Prebisch, R. 1964. Towards a new trade policy for development. New York: United Nations Conference on Trade and Development (UNCTAD).

Radnia, K. 2013. The relationship between inflation rate, oil revenue and taxation in Iran: OLS-based methodology. Journal of Economics and Sustainable Development, 4(19), 131-146.

Renani, H., Honarvar, N., Tavakolnia, M. 2013. A structural vector error correction (SVEC) model of the effects of oil shocks on macroeconomic indicators in Iran. Iranian Journal of Economic Modeling Research, 4(16), 73-98.

Roshani, H. 2016. Effect of oil revenues on money volume in Iran: The role of foreign-exchange fund. Iranian Journal of Economic Growth and Development, 6(23), 5974.

Rosser Jr, J.B., Sheehan, R.G. 1995. A vector autoregressive model for Saudi Arabian economy. Journal of Economics and Business, 47(1), 79-90.

Sala-I-Martin, X., Subramanian, A. 2003. Addressing the natural resource curse: An illustration from Nigeria. Cambridge, MA, NBER Working Paper, No. 9804.

Shahbazi, R., Emami, A., Boghzian, A. 2012. Comparison of the effect of oil price shocks on macroeconomic variables in Iran based on the definitions of crude oil price shocks. Master's thesis, Allameh Tabatabaei University, Tehran.

Shahnazi, R., Renani, M., Dalali Esfahani, R., Khoshakhlagh, R., Vaez, M. 2011. Optimal Fiscal Policy with Oil Revenues. Iranian Economic Review, 15(29), 73-88.

Zonouzi, J., Shahbazi, K., Parnak, R. 2014. Effect of oil revenues on good governance in selected OPEC member countries. Iranian Journal of Economic Development Policy, 2(4), 117-156. 